\title{
Volgian and Santonian-Campanian radiolarian events of the Russian Arctic and Pacific Rim
}

Valentina S. Vishnevskaya and Genrietta E. Kozlova

Acta Palaeontologica Polonica 57 (4), 2012: 773-790 doi: http://dx.doi.org/10.4202/app.2011.0040

Radiolarians are widely distributed in two siliceous intervals that coincide with the

Tithonian-Berriasian and Santonian-Campanian boundaries in the Mesozoic of the Russian

Arctic and Pacific Rim. The first level is rich in organic matter and typical of

Jurassic-Cretaceous boundary strata from the Russian North European Margin

(Barents-Pechora, Volga-Urals, and Siberian hydrocarbon provinces, as well as western

Kamchatka). Abundant and diverse representatives of the family Parvicingulidae provide a

basis for establishing the new genus Spinicingula (uppermost Middle

Volgian-Lower Berriasian); another new genus Quasicrolanium (Upper

Volgian-Upper Berriasian) is also described. A Santonian-Campanian siliceous

interval with radiolarians is documented from the margins of northern Asia

(eastern Polar Ural, Kara Basin, Kamchatka). The Boreal genus Prunobrachium makes its

first appearance at the Santonian-Campanian boundary and reaches an acme in Campanian strata. Radiolarian data can be used for basin biostratigraphy and correlation, as well as palaeogeographical interpretation of these hydrocarbon-rich facies. The Arctic and northern Pacific rims are well correlated on the basis of parvicingulids, while in Sakhalin these are absent and calibrations are based on Unitary Associations zones of the Tethys. In addition to the two new genera noted above, five new species (Parvicingula alata, Parvicingula papulata, Spinicingula ceratina, Lithostrobus borealis, and Spongurus arcticus) are erected, while 60 radiolarian species typical of the Russian Arctic and Pacific rims are illustrated.

Key words: Radiolaria, events, new taxa, organic-rich cherts, Cretaceous, northern Russia.

Valentina S. Vishnevskaya [valentina@ilran.ru], Geological Institute, Pyzhevsky lane 7, Moscow 119017, Russia; Genrietta E. Kozlova [genriett@mail.ru], VNIGRI, Litejnyj pr., 39, Sankt-Peterburg 191104, Russia. 
This is an open-access article distributed under the terms of the Creative Commons

Attribution License (for details please see creativecommons.org), which permits unrestricted use, distribution, and reproduction in any medium, provided the original author and source are credited.

FoF Full text $(1,102.7 \mathrm{kB})$ 